\title{
Effect of Bio-Agents, Neem Leaf Extract and Fungicides Against Alternaria Leaf Blight of Wheat (Triticum aestivum L.)
}

Sardar Singh Kakraliya ${ }^{1 *}$, Dechan Choskit ${ }^{2}$, Devanshi Pandit ${ }^{2}$ and Sonali Abrol ${ }^{2}$

${ }^{1}$ Department of Plant Pathology, Sam Higginbottom Institute of Agriculture, Technology and Sciences, Allahabad, Uttar Pradesh, India

${ }^{2}$ Division of Plant Pathology, SKUAST, Jammu and Kashmir, India

*Corresponding author: Kakraliya SS, Department of Plant Pathology, Sam Higginbottom Institute of Agriculture, Technology and Sciences, Allahabad, Uttar Pradesh, India, Tel: 8717088308; E-mail: sardarchoudhary70@gmail.com

Received: September 22, 2017; Accepted: October 05, 2017; Published: October 13, 2017

Copyright: (c) 2017 Kakraliya SS, et al. This is an open-access article distributed under the terms of the Creative Commons Attribution License, which permits unrestricted use, distribution, and reproduction in any medium, provided the original author and source are credited.

\begin{abstract}
The experiment was conducted under in vitro and field conditions to observe the effect of bio-agents, botanical and fungicides against Alternaria triticina. Eight treatments were taken up with three replications and data collected was analyzed using CRD. Maximum inhibition percent mycelia growth was observed in Propiconazole (89.72\%), Hexaconazole $(88.44 \%)$, Vitavax $(87.70 \%)$, followed by Trichoderma harzianum (85.50\%), Trichoderma viride (83.30\%), Pseudomonas fluorescens $(80.73 \%)$ and neem leaf extract $(73.57 \%)$ as compared to control $(0)$. An experiment was conducted under field condition to observe the effect of bio-agents, neem leaf extract and fungicides against Alternaria triticina. Eight treatments were taken up with three replications and data collected was analyzed using RBD. Maximum plant height $(\mathrm{cm})$ was observed in T. viride $(78.82 \mathrm{~cm})$ followed by $T$. harzianum $(78.27 \mathrm{~cm})$ as compared to control $(70.04 \mathrm{~cm})$. T. viride was significantly superior as compared to other treatments. Minimum disease intensity per cent and production of wheat was recorded in treatment Propiconazole @0.1\% (18.24\% and 37.00 q/ha respectively) followed by Pseudomonas fluorescens @0.5\% (20.51\% and 30.44 q/ha), as compared to control (43.18\% and $20.41 \mathrm{q} / \mathrm{ha})$. Propiconazole was significantly superior as compared to other treatments.
\end{abstract}

Keywords: Alternaria blight; Trichoderma spp; Fungicides; Neem leaf extract

\section{Introduction}

Wheat (Triticum aestivum $L$.) is the world's most extensively grown crop and important staple food. There are several constraints limiting the potential yield of wheat. Among them foliar blight has recently emerged as major concern throughout the world [1]. In India, foliar blight of wheat had been noticed as early as 1924 [2], but it was not of much consequence till recently. In the recent past, with the change in cropping system, foliar blight has now become a major disease far and wide in our country causing 2.72 to $36.24 \%$ yield losses under different agro climatic zones. In India, foliar blights of wheat are considered as one complex, which includes leaf blight caused by Alternaria triticina Prasada and Prabhu and spot blotch caused by Bipolaris sorokiniana. In the Indogangetic plains, covering the entire north-western and north-eastern plains, rice-wheat rotation is the dominant cropping sequence. It has been commonly observed that the intensity of foliar blights has considerably increased in the rice-wheat system [3]. During last decade multilocational surveys for determining incidence of foliar blights of wheat have been conducted in eastern U.P, Bihar, Haryana, Punjab, Delhi, Gujrat and Rajasthan [4-15]. In view of the growing concern about foliar blight of wheat, it was considered desirable to study the incidence of the disease and the causal organisms in Allahabad region where wheat (Triticum aestivum L.) is main food crop. Leaf blight caused by Alternaria triticina is the major disease in irrigated wheat in Vidarbha region of Maharashtra. Alternaria leaf blight was first reported from Maharashtra in 1924 [2]. The disease initially appears as small and irregularly scattered chlorotic lesions on the leaves in last week of December. As the disease progresses, several spots coalesce and cover the whole or part of the leaf giving it a blighted' appearance. Heavily infected fields show a burnt appearance $[5,16]$.

The normal sown as well as late sown irrigated wheat varieties were found heavily infected with Alternarialeaf blight during January and February in Vidarbha region, causing considerable losses in the grain yield of irrigated wheat. Therefore, this trial was formulated to estimate the losses caused due to leaf blight disease $[6,17]$.

The application of two irrigations reduced the severity of foliar blight as compared to no irrigation [7] Sreshta reported that low or imbalance soil nutrient levels predispose plants to more severe leaf blight attack found low incidence of disease when wheat crop was sowing on 30th November as compared 20th December [18-22]. Among the different diseases caused by the genus Alternaria blight disease is one of the most dominant one that causes average yield loss in the range of $32-57 \%$. Symptoms of this disease include presence of irregular, often circular brown to dark brown colour leaf spots on the leaves with concentric lines inside the spots. Often the circular spots coalesce to form large patches resulting in the leaf blight. In several cases, small dark coloured spots are also formed on pods and tender twigs [23]. For Alternaria blight management, early sowing of properly stored clean certified seeds after deep ploughing along with clean cultivation, timely weeding and maintenance of optimum plant population, avoidance of irrigation at flowering and pod formation stages are some of the steps to be followed for an efficient management of the disease [24].

Conidiophores of majority of the species of Alternaria produce asexual spores (conidia) measuring between 160-200 $\mu \mathrm{m}$ long. Under in vitro conditions, sporulation occurs at a temperature range of $8-24^{\circ} \mathrm{C}$, where mature spores occur after 14-24 h. Optimum temperatures are between 16 and $24^{\circ} \mathrm{C}$ where sporulation time ranges 
from 12 to $14 \mathrm{~h}$. Moisture in the presence of rain, dew or high humidity are essential for infection and a minimum of 9-18 h are required for majority of the species [10]. Continuous moisture of $24 \mathrm{~h}$ or longer practically guarantees infection [11]. Relative humidity of $91.5 \%$ (at $20^{\circ} \mathrm{C}$ ) or higher will result in the production of large numbers of mature spores in $24 \mathrm{~h} \mathrm{[10].}$

\section{Materials and Methods}

The present investigation was carried out during 2014-15 Rabi season at the Department of Plant Pathology Central Research field, Sam Higginbottom Institute of Agriculture Technology and Sciences (Deemed to-be University) Allahabad, India. A field study conducted to Present experiment with appropriate statistical design was conducted in the field conditions by adopting Randomized Block design (RBD) with eight treatments and each treatment was replicate three times [12-20]. The details of materials and methods followed during the course of present investigation are described below.

The seeds of variety PBW-343, which is highly susceptible to leaf blight were collected from Sam Higginbottom Institute of Agriculture Technology and Sciences (Deemed to-be University) Allahabad, (SHIATS), plant extracts viz. extracts of leaves of neem (Azadirachta indica and three BAU-Biofungicide (Trichoderma viride, Trichoderma harzianum, Pseudomonas fluorescens based preparation and which obtained from the Disease Resistance Laboratory) were used. Propiconazole Hexaconazole, Vitavax was used as chemical check.

\section{Preparation of plant extract}

Plant material are chopped in required quantity of water $(1: 1 \mathrm{w} / \mathrm{v})$, boiled for $30 \mathrm{~min}$ and then strain through cheese cloth to obtained standard plant extract solution (100\%) [21-23]. The extract is centrifuge at $5000 \mathrm{rpm}$ for $5 \mathrm{~min}$ and the clear supernatant was used as stock solution.

\section{Application of neem leaf extract (Azadirachta indica)}

Neem leaf extract was prepared according to Paul and Sharma. 400 $\mathrm{g}$ (fresh wt) mature leaves were homogenized in a pre-chilled pestle and mortar using chilled, sterilized distilled water. The extract was filtered through four layers of moisture muslin cloth. The final volume was adjusted to $1000 \mathrm{ml}$ with distilled water. The filter ate was centrifuged at $2000 \mathrm{~g}, 4^{\circ} \mathrm{C}$ for $15 \mathrm{~min}$. The supernatant thus obtained was designated as concentrated leaf extract. Dilution of 1:2 was made from this concentrated extract [25].

\section{Application of Trichoderma viride, Trichoderma harzianum and Pseudomonas fluorescens}

Talcum based formulation of Trichoderma viride manufactured by Yash Biotech Pvt. Ltd; Allahabad was used for field experiment. Before applying the talcum based formulation of $T$. viride in the field the c.f.u was checked in the laboratory seed treatment @10 g/ $\mathrm{kg}$ of T. viride was used. Foliar spray of $T$. viride was at 50 DAS @10 g/l of water and the subsequent spray was given at 15 days interval as suggested by Rathi and Singh [26].

\section{Preparation of fungicidal spray solution}

The spray solution of a desired concentration was prepared by adopting the following formula.
$V=\frac{C \times A}{\% a \cdot i}$

Where,

$\mathrm{V}=$ Volume/weight of commercial fungicide $\mathrm{ml}$ or $\mathrm{g}$

$\mathrm{C}=$ Concentration required

$\mathrm{A}=$ Volume of solution to be prepared

$\%$ a.i.=percentage of active ingredient in commercial product.

\section{c.f.u count of $T$. viride and $T$. harzianum formulation}

One gram of Trichoderma powder was weighed and the volume was made up to $10 \mathrm{ml}$ with sterilized distilled water and was shaking well (1:10) inside laminar flow hood. Out of this suspension $1 \mathrm{ml}$ was taken out and transferred to $9 \mathrm{ml}$ of sterilized distilled water in a test tube (1:100). Serial dilution were made similarly by transferring $1 \mathrm{ml}$ of each suspension to the subsequent tubes to get $10^{-7}$ dilution. $1 \mathrm{ml}$ of $10^{-7}$ suspension was transferred to sterilized Petri plates. $15 \mathrm{ml}$ of melted and cooled PDA medium was poured in these plates. The plates are rotated gently to give a uniform distribution and allowed to solidify [27-32]. The plates were incubated in an inverted position at $25 \pm 2^{\circ} \mathrm{C}$. After 3 days, average numbers of colonies were calculated per plates of T. viride and T. harzianum. Four colonies each were found per plate and the number of colony forming unit (c.f.u) present in $1 \mathrm{~g}$ was calculated by the following.

$$
\text { c. } f . u=\frac{\text { No. of colonies }}{\text { Amount plated } \times \text { dilution factor }}
$$

\section{c.f.u count of Pseudomonas fluorescens formulation}

Colony forming unit (c.f.u) of Pseudomonas fluorescens was done to check the viability and spore load in formulation before their application. One gram powder formation of $P$. fluorescens was weighed and added in $9 \mathrm{ml}$ of sterile distilled water, shaken well and label as $10^{-1}(1: 10)$. Made dilution serially up to $10^{-8}$ as given below: From the first dilution transferred $1 \mathrm{ml}$ of suspension to the dilution blank $10^{-2}$ with sterile pipette diluting the original suspension to 100 times $(1 / 100)$ or $\left.10^{-2}\right)$. From the $10^{2}$, transferred $1 \mathrm{ml}$ of suspension to $10^{-3}$ dilution blank with sterile pipette, thus diluting the original sample has been diluted $100000000\left(10^{-8}\right)$ [33-37]. From the dilution $10^{-4}-10^{-8}$ transferred $1 \mathrm{ml}$ of suspension while in motion, with the respective pipettes, to sterile petri dishes (Table 1). Added $15 \mathrm{ml}$ of King's B melted cold medium, mixed the contents of each plate by rotating gently. Allowed the plates to solidify and incubated in inverted position for 24 to $48 \mathrm{hrs}$ at $25 \pm 2^{\circ} \mathrm{C}$ [34].

$$
\text { c. } f . u=\frac{\text { No. of colonies }}{\text { Amount plated } \times \text { dilution factor }}
$$

The scale for disease assessment was as follows:

\begin{tabular}{|l|l|l|l|l|}
\hline $\begin{array}{l}\text { S. } \\
\text { No. }\end{array}$ & $\begin{array}{l}\text { Per cent leaf } \\
\text { area covered }\end{array}$ & Grade $(\mathbf{x})$ & $\begin{array}{l}\text { No. of leaf } \\
\text { falling } \\
\text { in grade }(\mathbf{y})\end{array}$ & $\begin{array}{l}\text { Disease rating } \\
\left(\mathbf{x}^{*} \mathbf{y}\right)\end{array}$ \\
\hline 1 & 0 & 0 & - & - \\
\hline 2 & 1 & 1 & - & - \\
\hline 3 & $02-$ Oct & 3 & - & - \\
\hline 4 & Nov-25 & 5 & - & - \\
\hline
\end{tabular}




\begin{tabular}{|l|l|l|l|l|}
\hline 5 & $26-50$ & 7 & - & - \\
\hline 6 & $50>$ & 9 & - & - \\
\hline & & Total & - & - \\
\hline
\end{tabular}

Table 1: Scale of disease assessment.

\section{Disease intensity (\%) was calculated by using the following formula}

\author{
Disease intensity (\%) \\ Sum of all disease ratings Disease intensity (\%) \\ $=\frac{\text { Total number of leaves } / \text { plant } \times \text { Maximum disease grade }}{\times 100}$ \\ $\times 100$
}

\section{In vitro experiment}

The in vitro trial was laid out in completely randomized design (CRD) with three replications and eight treatments including check in the experimental laboratory of department of Plant Pathology. The management of leaf blight of wheat, with bio-agents, neem leaf extract and fungicides was tested applying poison food and dual culture techniques against Alternaria triticina. The observation of the mycelial growth inhibition per cent was recorded at 1 to 7 days [38-45].

\section{Cleaning and sterilization of glassware}

The glasswares (Petri dishes, pipettes, conical flasks, test tubes etc.,) used in the experiment were thoroughly washed with detergent powder and air dried. The Petri dishes and pipettes were wrapped in clean paper and sterilized in hot air oven at $160^{\circ} \mathrm{C}$ for $2 \mathrm{hrs}$.

\section{Poisoned food technique}

The poisoned food technique was followed to evaluate the efficacy of propiconazole (Tilt 25 EC) @0.1\%, hexaconazole @0.5\% and vitavax $@ 0.25 \%$ in laboratory against Alternaria triticina with three replications each. Mycelial disc of $5 \mathrm{~mm}$ size from seven days old cultures was cut out by a sterilized cork borer and one such disc was placed at the center of each agar plate. Check treatment was maintained without adding any fungicides to the medium [46,47]. After incubation for 24 to $168 \mathrm{hrs}$, at room temperature, radial growth was measured till fungus attained maximum growth in check plates. The efficacy of the fungicides was expressed as percent inhibition of mycelial growth over check, which was calculated by using the formula by Vincent $[14,48]$.

\section{Preparation of Potato Dextrose Agar (PDA) medium}

The culture media used in experiment were prepared according to the standard formula given by for isolating and growing of pathogen Alternaria sp. Potato dextrose agar (PDA) medium was used the composition of PDA is as follows composition of PDA [49]. Two hundred gram washed, peeled and sliced potatoes were boiled in 500 $\mathrm{ml}$ of distilled water in a sauce pan till they were easily penetrated by glass rod. The extract obtained was filtered through muslin cloth and all the liquid was squeezed in a beaker, $20 \mathrm{~g}$ agar was added bit to the rest of $500 \mathrm{ml}$ hot water to dissolve. Then $20 \mathrm{~g}$ of dextrose was added [50]. Volume of broth was made up to $1000 \mathrm{ml}$ by adding more distilled water. Then $200 \mathrm{ml}$ of this solution was dispensed in conical flasks [51-53]. These conical flasks were plugged with non-absorbent cotton and sterilized at $121^{\circ} \mathrm{C}$ at $15 \mathrm{lbs} /$ inch $^{2}$ for 20 minutes in an autoclave.

\section{Preparation of nutrient agar medium}

Boil one liter of distilled water, to this add beef extract, when this was dissolved added peptone and $\mathrm{NaCl}$. The pan was then taken down from the flame and agar was added with regular stirring. $\mathrm{pH}$ (7.0-7.2) was tested with the help of $\mathrm{pH}$ paper [54]. The media was transferred to test tubes and conical flasks and plugged with cotton. The media was then subjected to autoclave at $15 \mathrm{lbs}$ pressure per sq inch or $121^{\circ} \mathrm{C}$ for 20 minutes [55].

\section{Colony growth inhibition assay with Trichoderma spp. and Pseudomonas fluorescens in dual culture method}

Firstly, the antagonistic activity of Trichoderma viride, T. harzianum and Pseudomonas fluorescens against Alternaria triticina was studied in dual culture method [15]. So the antagonist was evaluated by dual culture technique. The pathogen was inoculated on one side of the petri plate filled with $20 \mathrm{ml}$ of PDA and antagonist was inoculated at exactly opposite side of the same plate by leaving 3-4 cm gap. For this, actively growing 7 days old culture was used. Dual inoculation of the pathogen and an antagonist was set up [56-60]. Culture discs of $5 \mathrm{~mm}$ dia were cut from the periphery of the actively growing colonies using a sterilized cork borer. Disc of test fungus was placed aseptically at the edge of the Petri plate. These plates were incubated at $25 \pm 1{ }^{\circ} \mathrm{C}$ for 48 hours. Mycelia disc (5 $\mathrm{mm}$ ) of antagonist was inoculated on opposite side of Petri plate three days after the pathogen to adjust for the slow growth rate of the pathogens. Paired cultures were again incubated at $25 \pm 1{ }^{\circ} \mathrm{C}$ for $24-168$ hours and observed periodically. Then antagonistic fungi were tested against Alterneria triticina. Each set was made in 3 replicates [61,62].

\section{$\mathrm{T} 1=$ Alterneria triticina + Trichoderma harzianum \\ $\mathrm{T} 2=$ Alterneria triticina + Trichoderma viride}

$\mathrm{T} 3=$ Alterneria triticina + Pseudomonas fluorescens

\section{Mycelium Inhibition \% calculated by the following formula}

Inhibition $\%=\frac{\text { Growth in Control }- \text { Growth in Treatment }}{\text { Growth in Control }} \times 100$

\section{Isolation of Alternaria triticina}

Wheat crop sowing characteristic symptoms of leaf blight were collected from Center Research Farm SHIATS, Allahabad. Infected leaf blight samples were thoroughly washed in running tap water and cut into small pieces of $2-5 \mathrm{~mm}$ size having half healthy tissues. After surface sterilization with Sodium hypochlorite $(0.1 \%)$ for $30-60$ seconds, infected leaf blight pieces were thoroughly washed three times in sterilized water and blotted dry on clean sterile blotting paper to remove the moisture. These pieces were transferred aseptically into Petri plates containing potato dextrose agar (PDA) medium [63]. The inoculated Petri plates were incubated in a B.O.D incubator at $28 \pm$ $1^{\circ} \mathrm{C}$. After 48 hours of incubation, mycelia growth developed at the margin was transferred to PDA slants. The pathogen culture was maintained on PDA in culture tubes and stored in refrigerator for further use. 
Citation: Kakraliya SS, Choskit D, Pandit D, Abrol S (2017) Effect of Bio-Agents, Neem Leaf Extract and Fungicides Against Alternaria Leaf Blight of Wheat (Triticum aestivum L.). Nat Prod Chem Res 5: 295. doi:10.4172/2329-6836.1000295

Page 4 of 7

\section{Morphological studies of the pathogen}

A morphological study of the pathogen was conducted from pure culture of Alternaria triticina spore suspension was made from pure culture of the pathogen grown on PDA. One drop of the spore suspension was placed on a slide and morphological characters were examined under compound microscope (Figure 1).

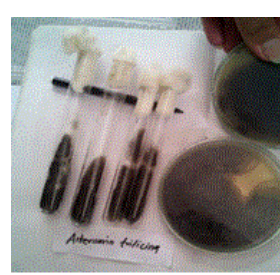

(A) Cultuer of Alternaria triticine

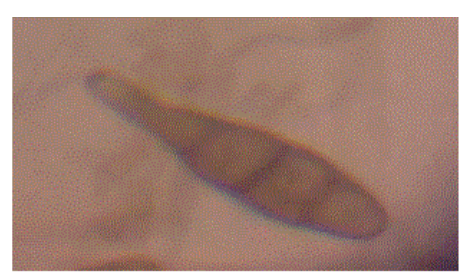

(B) Conidium of Alternaria triticina
Figure 1: Morphological study of the pathogen.

\section{Characteristics of pathogen (Alterneria triticina)}

- The mycelium of this fungus is hyaline. But later on it become alive buff in appearance.

- The conidiophores are septets usually unbranched, erect, single or in groups emerging out through the stomata.

- The conidiophores were light brown and septate.

- The conidia were usually yellowish brown in colour.

- The conidia may either be in chain or borne on conidiophores.

\section{Description of conidium}

- Colour: light brown to olive and become darker with age

- Shape: Irregularly oval, ellipsoid conical, gradually tapering into a beak

- Dimensions: $15-92 \times 8-35 \mu \mathrm{m}$

- Septa: 1-10 transverse and 0-5 longitudinal.

\section{Results and Discussion}

\section{Effect of bio-agents, neem leaf extract and fungicides against on mycelia growth of Alternaria}

Antagonistic activity of Trichoderma viride, Trichoderma harzianum and Pseudomonas fluorescens and were investigated by dual culture method on PDA. Data reveals that, Trichoderma viride, Pseudomonas fluorescens were potential antagonists of Alternaria triticina forming a clear zone of inhibition. On microscopic examination hyphae of antagonists were observed coiling and oppressed around hyphae of Alternaria triticina, T. harzianum (85.50\%) was most effective over other treatments followed by Trichoderma vridie (83.30\%) and Pseudomonas fluorescens $(80.73 \%)$ were least effective (Table 2 and Figure 2).

The efficacy of different fungicides and neem leaf extracts against Alternaria triticina were assayed in vitro. Observations were recorded on growth of the test fungus. Under various treatments, the observations recorded on per cent inhibition of growth are presented in Table 2 and Figure 2 that all the treatment at all the concentration inhibited the fungal growth and the data also revealed that the all the fungicides and neem leaf extracts were significantly superior over check at all the treatment propicanazole, hexaconazole, vitavax and neem leaf extract gave complete growth inhibition of Alternaria triticina.

\begin{tabular}{|l|l|l|}
\hline Treatments & $\begin{array}{l}\text { Radial growth of Pathogen } \\
\text { (cm) }\end{array}$ & $\begin{array}{l}\text { Per cent inhibition } \\
\text { (\%) }\end{array}$ \\
\hline Control & 5.45 & 0 \\
\hline Propiconazole & 0.56 & 89.72 \\
\hline Hexaconazole & 0.63 & 88.44 \\
\hline Vitavax & 0.67 & 87.7 \\
\hline Trichoderma viride & 0.91 & 83.3 \\
\hline $\begin{array}{l}\text { Pseudomonas } \\
\text { fluorescens }\end{array}$ & 1.05 & 80.73 \\
\hline Trichoderma harzianum & 0.79 & 85.5 \\
\hline Neem leaf Extract & 1.44 & 73.57 \\
\hline Mean & 11.5 & \\
\hline F-test & $\mathrm{s}$ & \\
\hline SEd (+) & 0.1 & \\
\hline CD (5\%) & 0.21 & \\
\hline
\end{tabular}

Table 2: Effect of bio-agents, neem leaf extract and fungicides against on mycelia growth of Alternaria.

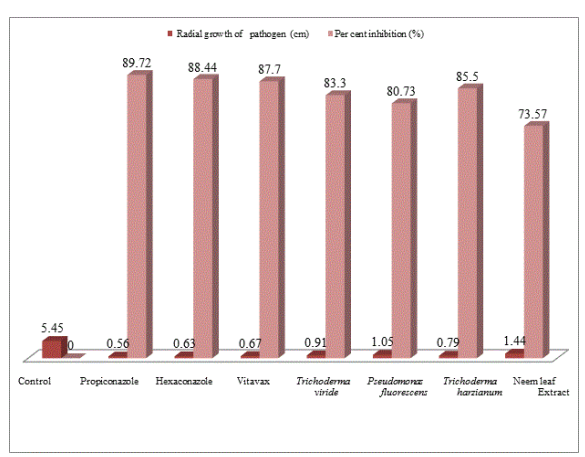

Figure 2: Effect of bio-agents, neem leaf extract and fungicides against on mycelia growth of Alternaria.

A significant difference in data presented on inhibition per cent of mycelium growth was observed among the treatment. Maximum inhibition per cent was recorded on propicanazole (89.72\%) except at it was followed by hexaconazole $(88.44 \%)$, vitavax $(87.70 \%)$ and neem leaf extract (73.57\%).

Besides the agricultural practices, physical and biological methods used for the management of diseases caused by Alternaria triticina, chemical fungicides are most commonly adopted by the growers. Fungicides like; Propicanazole, carbendazim, hexaconazole, ridomil and topsin etc., have been recommended against Alternaria. Such synthetic fungicides bring about the inhibition of pathogens either by 
destroying their cell membrane or its permeability or by inhibiting metabolic processes of the pathogen and hence are extremely effective.

\section{Effect of fungicides on the disease intensity of leaf blight of wheat}

BAU-Biofungicide and botanical differed in respect of leaf blight disease Intensity (\%) at different growth stages (Table 3). At 45 DAS, the lowest (16.18\%) disease intensity was recorded with Propiconazole @0.1\% Follwed by Hexaconazole @0.5\% (17.92\%). The highest disease incidence was recorded in control (33.00\%), followed by Pseudomonas fluorescens (19.15\%), vitavax @0.25\% (22.13\%) Trichoderma viride (22.26\%), Trichoderma harzianum (23.03\%) and neem leaf extract $@ 10 \%$ (23.50\%). At 90 DAS, the lowest (18.24\%) disease intensity was recorded with Propiconazole @0.1\%. While the highest (43.18\%) was recorded in control plot. Among the BAU fungicides and botanicals Propiconazole @0.1\% and Pseudomonas fluorescens, performed better than other BAU fungicides and botanicals to reduce per cent disease intensity of the leaf blight disease (Table 3 and Figure 3).

\section{Effect of BAU-fungicides and botanicals on the yield of leaf blight of wheat}

Among the bio-agents, botanical and fungicides used the maximum grain yield was recorded in Propicanazole @0.1\% (37.00) as compared to untreated control (20.41) followed by Hexaconazole @0.5\% (34.63), vitavax @0.25\% (32.20), Pseudomonas flourescens (30.44), Trichoderma viride (28.89), Trichoderma harzianum (27.04) and neem leaf extract @10\% (26.37) (Table 3).

\begin{tabular}{|l|l|l|l|l|}
\hline \multirow{2}{*}{ Treatment (\%) } & \multicolumn{2}{|l|}{ PDI } & $\begin{array}{l}\text { Yield } \\
\text { (qlha) }\end{array}$ & $\begin{array}{l}\text { C:B } \\
\text { Ratio }\end{array}$ \\
\cline { 2 - 5 } & $\begin{array}{l}45 \\
\text { DAS }\end{array}$ & $\begin{array}{l}90 \\
\text { DAS }\end{array}$ & \multicolumn{2}{|}{} \\
\hline Control & 33 & 43.18 & 20.41 & $01: 01.0$ \\
\hline Propiconazole @0.1\% & 16.18 & 18.24 & 37 & $01: 01.4$ \\
\hline Hexaconazole @0.5\% & 17.92 & 19.94 & 34.63 & $01: 01.4$ \\
\hline Vitavax @0.25\% & 22.13 & 24.55 & 32.2 & $01: 01.5$ \\
\hline Trichoderma viride @2\% & 22.26 & 25.51 & 28.89 & $01: 01.4$ \\
\hline $\begin{array}{l}\text { Pseudomonas } \\
\text { @2.5\% }\end{array}$ & 19.15 & 20.51 & 30.44 & $01: 01.4$ \\
\hline Trichoderma harzianum @2\% & 23.03 & 25.76 & 27.04 & $01: 01.3$ \\
\hline Neem leaf extract @10\% & 23.5 & 28.48 & 26.37 & $01: 01.2$ \\
\hline S.Ed. (+) & 0.78 & 0.73 & 0.5 & - \\
\hline C.D. (P=0.05\%) & 1.67 & 1.56 & 1.07 & - \\
\hline PDI=Per cent disease intensity & & & & \\
\hline DAS=Date after sowing & & & & \\
\hline C:B=Cost Benefit ratio & & & & \\
\hline
\end{tabular}

Table 3: Effect of bio-agents and plant extracts on disease intensity of wheat.

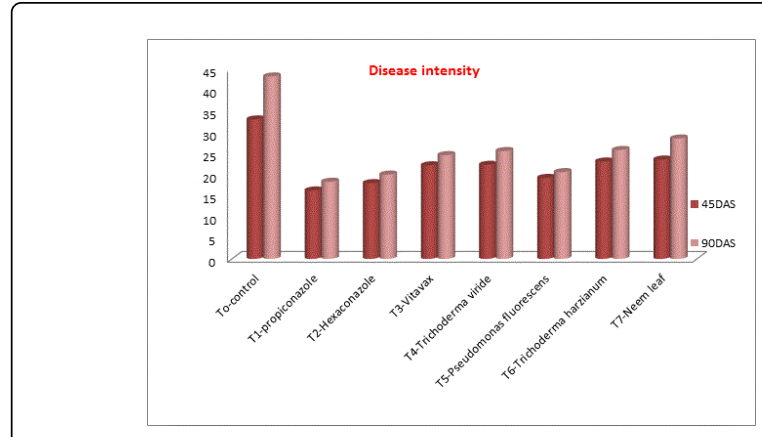

Figure 3: Effect of bio-agents and plant extracts on disease intensity of wheat.

Among the treatments most effective was propicanazole @0.1\% (37.00) and hexaconazole @0.5\% (34.63), However, the treatments neem leaf extract and Trichoderma harzianum were non-significant and statistically at par with each other [64]. The results of the present study are in accordance to the findings of the Nargund, they reported that in the present result showed that all the treatments tested in this study gave satisfactory result against Alternaria triticina.

Among all the treatment, systemic fungicides such as propicanazole and hexaconazole reduced that Alternaria triticina intensity and leaves become disease free [65]. Healthy leaves have more photosynthetic activity, ultimately enhance the number of ears. But the efficacy of bioagent such as Pseudomonas fluorescens, Trichoderma viride and Trichoderma harzianum were less as compared to the systemic fungicides [51].

Results showed that the highest yield was recorded in Propicanzole (37.00 q/ha), followed by Pseudomonas flourescens @0.5\% (30.44), reported that use of chemical inducers had adverse effect on the plant growth. But given highest yield because chemicals attributed to elicitor's effect on physiological processes in plant such as ion uptake, cell elongation, cell divition, enzymatic activation and protein synthesis [66].

All treatments are significant to each other and statistically at par with each other. When cost benefit ratio was worked out, interesting result was achieved. Among the treatment studied, the best and most economical treatment was vitavax @0.25\% (1:1.52), Trichoderma viride (1:1.43), propicanazole @0.1\% (1:1.42), Hexaconazole @0.5\% (1:1.36) followed by Pseudomonas fluorescens (1:1.38), Trichoderma harzianum (1:6.48), and neem leaf extract (1:1.22), as compared to control (1:1.03).

The application of Trichoderma viride reduces the pathogen population in soil by means of mycoparasitism and production of antibiotic which may be reduce the soil borne pathogens in soil. The inhibition of fungal growth due to Trichoderma spp. may have been due to secretion of extracellular cell degrading enzymes such as chitinase B-1, 3-glucanase, cellulose and lectin, which may have helped mycoparasites in the colonization of their host. The inhibition of pathogen may also be attributed to the production of secondary metabolites by antagonists such as glioviridin, viridian and gliotoxin $[67,68]$. 


\section{Conclusion}

All the plant extracts and BAU-Biofungicide significantly inhibited mycelial growth of the pathogen. BAU-Biofungicide showed maximum $(89.72 \%)$ reduction of mycelial growth and based on the results, Pseudomonas fluorescens @2.5\% was found the most effective treatment which gave recorded minimum disease intensity (\%) and yield ( $\mathrm{q} / \mathrm{ha})$, as compared to other treatments except Tilt @0.1\% (propiconazole) which was taken as treated control. so it may be concluded that bio-agents along with propiconazole @0.1\% can be use for the management of leaf blight of wheat. The present research findings are limited to one crop season (December 7- April 11) under Allahabad agro-climatic conditions as such more trials are required in future to validate the findings.

\section{Acknowledgment}

This manuscript is the part of M.Sc. (Ag) thesis work. Hence, the authors would like to thank the Department of Plant Pathology, SHUATS Allahabad, for providing the necessary facilities.

\section{References}

1. Dubin HJ, Van GM (1991) The status of wheat diseases and disease research in the warmer areas. In: Wheat for non traditional warm areas. pp: 125-145.

2. Kulkarni GS (1924) Reported of the work done in plant pathology section during the year 1922-23. Ann Rept Dept Agric, pp: 167-171.

3. Nagarajan S, Kumar J (1998) Foliar blights of wheat in India In Helminthosporium blights of wheat, spot blotch and tan spot. Proceedings of an International workshop held at CIMMYT, Mexico, pp: 52-58.

4. Singh SK, Srivastava KD, Singh DV (2004) Pathogenic behaviour of leaf blight organisms on wheat. Indian Phytopathol 57: 319-322.

5. Sokhi P, Joshi LM (1972) Multiplication of inoculum of Al-ternaria triticina for field inoculations. Indian J Microbiol 12: 108-109.

6. Shivankar SK, Shivankar RS, Nagone AH (2000) Evaluation of fungicides against Alternaria leaf blight of wheat. Indian J Sci 32: 243-249.

7. Shrestha KK, Timla RD, Mahato BN, Bim HB (1998) Disease incidence and yield loss due to foliar blight of wheat in Nepal. In: Helminthosporium blights of wheat. Indian J Mycol Plant Pathol 23: 112-116.

8. Valkonen JPT, Koponen H (1990) The seed-borne fungi of Chinese cabbage (Brassica pekinensis), their pathogenicity and control. Plant Pathology 39: 510-516.

9. Meena PD, Chattopadhyay C, Singh F, Singh B, Gupta A (2002) Yield loss in Indian mustard due to white rust and effect of some cultural practices on Alternaria blight and white rust severity. Brassica 4: 18-24.

10. Humpherson-Jones FM, Phelps K (1989) Climatic factors influencing spore production in Alternaria brassicae and Alternaria brassicicola. Ann Appl Biologic Sci 114: 449-458.

11. Chupp C, Sherf AF (1960) Vegetable diseases and their control. The Ronald Press Company, New York, USA, pp: 267-269.

12. Sanjay G, Ashok K (2006) Azadirachta indica leaf extract induces resistance in sesame against Alternaria leaf spot disease. Journal of Cell and Molecular Biology 5: 81-86.

13. Rathi AS, Singh D (2009) Integrated management of Alternaria blight and white rust in Indian mustard.

14. Vincent JM (1927) Distortion of fungal hypha in presence of certain inhibitor. Nature 159: 850 .

15. Falck R (1907) Wachstumgesetze, Wachstufakoren and Temperature were der holzerstorenden. Mycelien 1: 153-154.

16. Copes WE (2009) Concentration and intervals of chemicals application to control Puccinia hemerocallpdis on day lily. J Crop Protec 28: 24-29.
17. Gharib FA, Hegazi AZ (2010) Salicylic acid ameliorates germination, seedling growth, phytohormone and enzymes activity in bean (Phaseolus vulgaris L.) under cold stress. J Am Sci 6: 675-683.

18. Kalmesh M, Gurjar RBS (2002) Evaluation of different fungal antagonistic, plant extracts and oil cakes against Rhizoctonia solani causing stem rot of chilli seedlings. Ann Pl Protec Sci 10: 319-322.

19. Ainsworth GC, Haworth DL, Suttahi BC (1973) Dictionary of the fungi. Common wealth Mycology Institute, Kew, United Kingdom.

20. Babana AH, Amadou HD, Kadia M, Traoré D (2012) Investigations on fungicidal sensitivity of Trichoderma spp. and Sclerotium rolfsii (collar rot pathogen) in crossandra. Internat J Appl Bio Pharm Techonol 2: 290-293.

21. Mamgain A, Roychowdhury R, Tah J (2013) Alternaria pathogenicity and its strategic controls. Res J Biol 1: 1-9.

22. Agale RC, Kadam JJ, Joshi MS, Borkar PG (2014) Symptomatology of purple blotch disease of onion and exploration of fungicides, phytoextract and bio-agents against causal fungus Alternaria porri. Hist 11: 63-69.

23. Aneja KR (2003) Experiment in Microbiology, Plant Pathology and Biotechnology. New Age International (P) Limited, Publishers. New Delhi, pp: 147-156.

24. Bhoyar PR, Chandankar VD, Bagde VL, Dipali B, Borkar Sonone JS (2014) Studies on seed borne mycoflora and effect of Bio-agents and fungicides on wheat seed health. Internat Quart J Life Sci Plant Pathol 9: 1285-1289.

25. Brahma RN, Asir R, Aloka G, Saikia K (1991) Efficacy of Tilt (propiconazole) on different wheat cultivars. Indian Phytopathol 44: 116-118.

26. Conn KL, Tewari JP (1990) Survey of Alternaria blak spot and Sclerotinia stem rot in central Alberta in 1989. Can Plant Dis Survey 70: 66-67.

27. Copes WE (2009) Concentration and intervals of chemicals application to control Puccinia hemerocallpdis on day lily. J Crop Protec 28: 24-29.

28. Chattopadhyay AK, Bhunia CK (2003) Management of Alternaria leaf blight of rapeseed-mustard by chemicals. J Myc Patholog Res 41: 181-183.

29. Couillerot O, Combaret C, Prigent MJ, Loccoz YM (2008) Pseudomonas fluorescens and closely-related fluorescent pseudomonads as bio-control agents of soil-borne. Phyto Pathogen Appl Microbiol 48: 505-512.

30. Dubuis C, Keel C, Haas D (2007) Dialogues of rootcolonizing biocontrol pseudomonads. European J Plant Pathol 119: 311-328.

31. Dharamsingh A, Maheshwari VK (2001) Biological seed treatment for the control of leaf blight of wheat. Ind Phytopathol 54: 457-460.

32. Dey U, Harlapur SI, Dhutraj DN, Suryawanshi AP, Badgujar SL, et al. (2012) Spatiotemporal yield loss assessment in corn due to common rust caused by Puccinia sorghi Schw. Europ J Scien Res 36: 260-268.

33. Halgekar SK, Ramachandra CG, Kalappanavar IK (2014) Evaluated the affect of different antagonist viz. Trichoderma viride, Pseudomonas fluorescens and Bacilus substilis against different seed brone fungi of rice. Internation J Agricul Sci 2: 503-504.

34. Haas D, De'fago G (2005) Biological control of soilborne pathogens by fluorescent pseudomonads. Nat Rev Microbiol 3: 307-319.

35. Hossain I, Rahman MH, Aminuzzaman FM, Ahmed F (2001) Efficacy of fungicide and botanicals in controlling leaf blight of wheat and its cost analysis. Pakistan J Biol Sci 4: 178-180.

36. Kavina J, Gopi R, Panneerselvam R (2012) The effect of different triazole compounds, viz. difenoconozole (DIZ) and propiconazole (PPZ) treatments on the antioxidant potentials of Gloriosasuperba. Agricul Sci Digest 20: 193-194.

37. Kabir MH, Aminuzzaman FM, Islam MR, Chowdhury MS (2007) Effect of physical and chemical seed treatments on leaf spot (Bipolaris sorokiniana) and yield of wheat. World J Agricul Sci 3: 306-315.

38. Kalappanavar K, Patidar RK, Kulkarni S (2008) Management Strategies of Leaf Rust of Wheat Caused by Puccinia recondite $f$ sp.Tritici Rob. ex. Desm. J Agricul Sci 21: 61-64.

39. Khan MA, Ilyas MB (1996) Effect of foliar applied fungicides on wheat varieties infected by Puccinia recondite f.sp. tritici and Drechslera sorokiniana. J Agricul Sci 1: 7-11. 
Citation: Kakraliya SS, Choskit D, Pandit D, Abrol S (2017) Effect of Bio-Agents, Neem Leaf Extract and Fungicides Against Alternaria Leaf Blight of Wheat (Triticum aestivum L.). Nat Prod Chem Res 5: 295. doi:10.4172/2329-6836.1000295

Page 7 of 7

40. Kumar RN, Mukherjee KC (1996) Integrated disease management future perspective advances in botany. APH Publishing Corporation, New Delhi, pp: 335-347.

41. Kaushik R, Sharma N, Swami N, Sihag M, Goyal A, et al. (2013). Physicochemical properties, extraction and characterization of gluten from different Indian wheat cultivars. Res Rev J Crop Sci 2: 37-42.

42. Kumar AK, Jaleel CA, Manivannan P, Sankar B (2006) In the present investigation, the impact of hexaconazole (HEX) and paclobutrazol (PBZ), triazole fungicides, on the leaf anatomy of Chinese potato (Solenostemon rotundifolius Poir., J.K. Morton) was studied. Indian J Agricul Sci 78: 513-517.

43. Islam MT, Faruk AN (2008) Effect of selected soil amendments on seed germination, seedling growth and control of damping-off of chilli seedlings. J Sher-e-Bangla Agricul Univer 2: 12-16.

44. Manu TG, Nagaraja AC, Janawad S, Vinayaka H (1994). The impact of propiconazole (Tilt 250EC) on the growth and the breading of hard wheat isolated roots (Triticum durum, GTA dur and Vitronvarieties). African J Agricul Res 2: 370-373.

45. Maleki M, Mostafaee S, Mokhtarnejad L, Farzaneh M (2010) Characterization of Pseudomonas fluorescens strain CV6 isolated from cucumber rhizosphere inVaramin as a potential biocontrol agent. Aus J Cr Sci 4: 676-683.

46. Mahmodol Hasan M (2013) Biological Control of Wheat Caused by Bipolaris sorokiniana, Fusarium graminearum and Aspergillus flavus with Antagonist's of Trichoderma spp. Bangla J Plant Pathol 2: 1-9.

47. Mahbubur Rahman M, Barma NCD, Malaker PK, Karim MR, Khan AA (2009) Integrated Management for the Bipolaris Leaf Blight and Foot and Root Rot Diseases of wheat. Intern J Sustain Crop Prod 4: 1-4.

48. Malaker PK, Mian IH (2009) Effects of seed treatment and foliar spray with fungicides in controlling black point disease of wheat. Bangla J Agricul Res 34: 425-434.

49. Nene YL, Thapliyal PN (1993) Fungicides in plant disease control. (3rd edn), Oxford and IBH Publishing Co., Pvt. Ltd., New Delhi, pp: 526-531.

50. Prabhu AS, Prasada R (1970) Investigations on the leaf blight disease of wheat caused by Alternaria triticina. Indian Phytopathol 23: 19-27.

51. Percival J (1921) The wheat plant. A monograph, E.P. Dutton and Company. New York, USA, p: 463

52. Parashar M, Nagarajan S, Goel LB, Kumar J (1995) Report of the coordinated experiments 1994-95. Crop Protection, AICWIP, Directorate of Wheat Research, Karnal, p: 206.

53. Parveen S, Kumar VR (2001) Studies on the seed-borne nature of leaf blight of wheat. J Mycol Plant Pathol 31: 292.
54. Pramod K, Fateh S, Ravindra K, Hussain MF, Ajay PS (2014) Effect of Temperature on Performance of Wheat Varieties under Semi-arid Conditions of Uttar Pradesh. Intern J Sci Eng Technol 3: 551-552.

55. Rosyara UR, Sharma RC, Shrestha SM, Duveiller E (2005) A study of pathosystems. Management by chemicals. CAB International Publishing, 34: 316-331.

56. Rahman MM, Nahar MS, Karim MM, Begum K (2013) Efficacy of fungicides in controlling leaf blight of wheat. Intern J Expt Agric 3: 1-3.

57. Ramachandra CG, Kalappanavar IK (2006) Non-chemical management strategy for leaf blight of dicoccum wheat. Intern J Agricul Sci 2: 503-504.

58. Ratika S, Sengar RMS, Surendra S (2012) Foliar blights of wheat include the leaf blight and blotches which are caused by Alternaria and Helminthosporium species respectively. Indian J Sci 1: 39-41.

59. Saari EE, Wilcoxson RD (1974) Plant disease situation of high-yielding dwarf wheats in Asia and Africa. Ann Rev Phytopathol 12: 49-68.

60. Sapirstein HD, David P, Preston KR, Dexter JE (2007) Durum wheat bread making quality: Effects of gluten strength, protein composition, semolina particle size and fermentation time. J Cereal Sci 45: 150-161.

61. Singh R (2009) Plant diseases. Oxford and IBH Publishing Co. Pvt. Ltd. pp: $147-160$.

62. Sunita M, Srikanta D (2013) Bio-efficacy of botanicals against Alternaria leaf blight of mustard under field condition. Intern Publishing 8: 675-679.

63. Singh VK, Singh G, Bhattacharya PM (2005) Incidence of Helminthosporium leaf blight of wheat and biochemical back-ground of disease resistance in the Eastern Gangetic Plains. J Wheat Res 3: 26-28.

64. Singh DP, Sharma AK, Pankaj Chowdhury AK, Singh KP, Mann SK, et al. (2008) Management of leaf blight of wheat (Triticum aestivum) caused by Bipolaris sorokinana and Alternaria triticina in different agroclimatic zones using an intergrated approach. Indian J Agricul sci 78: 513-517.

65. Vijayalakshmi K, Radha KS, Vandana S (1995) Neem a user's manual, foundation for science, technology, and natural resource policy, New Delhi, p: 96.

66. Wieser H (2007) Chemistry of gluten proteins. Food Microbiol 24: 115-119.

67. Waghe KP, Wagh SS, Kuldhar DP, Pawar DV (2015) Evaluation of different fungicides, bioagents and botanicals against alternaria blight caused by Alternaria helianthi of sunflower. African J Agricul Res 10: 351-358.

68. Zobaer ASM, Aminuzzaman FM, Chowdhury MSM, Miah MS (2007) Effect of seed sorting, solarization and treatment with vitavax-200 and hot water on leaf spot disease and yield of wheat. Bangla J Seed Sci Techonol 11: 11-15. 